\title{
Climbing Career Steps: Becoming a Full Professor of Economics*
}

\author{
Ali C. Tasiran \\ U niversity of G othenburg, S-411 80 G othenburg, Sweden and U niversity of M ichigan, \\ A nn A rbor, MI 48106-1248, USA
}

\section{Ann Veiderpass and Bo Sandelin \\ U niversity of G othenburg, S-411 80 G othenburg, Sweden}

\begin{abstract}
Event history analysis is used to examine the process of becoming a full professor of economics in Sweden. The data encompass 256 Swedish doctors' dissertations in economics between 1951 and 1989. A piecewise constant exponential model is specified for the transition risk of becoming a full professor. The risk decreases with age at the defense of a doctoral thesis and increases with the current popularity of the chosen topic and with the number of times appointed faculty opponent. There is no indication of individual-specific unobserved heterogeneity in the preferred model.
\end{abstract}

\section{Introduction}

What influences the changes of being appointed professor of economics in Sweden? A re there any common denominators in professional histories that may affect an aspiring economist's career outcome in this respect? Even though good theoretical models do not exist, and previous approaches are not sufficient to provide any answers, this study attempts, for the first time, to address these issues.

E ver since the 1960s, when the economics of education with its concept of human investment was established through pioneering work primarily by M incer (1958), Schultz (1961) and Becker (1964), there have been numerous empirical studies of different aspects of the supply of and demand for different levels of education. A lthough the general framework of this kind of study may be of relevance here, ${ }^{1}$ the focus of our study is not

\footnotetext{
* We thank participants at a seminar at Koc U niversity, I stanbul, A pril 1995, participants at the Econometric Society 7th World Congress, Tokyo, August 1995, as well as Eskil Wadensjö, Björn Gustafsson, Lennart Hjalmarsson, Karl O. Moene and two anonymous referees for valuable comments. Financial support from The Swedish Council for R esearch in the Humanities and Social Sciences (HSFR) is gratefully acknowledged.

${ }^{1}$ The act of choosing post-graduate education is naturally a prerequisite for being eligible for a chair at some later stage and, theoretically speaking, is in accordance with the hypothesis that education has a sorting function. The choice may also be characterized in terms of education regarded as consumption rather than as an investment to ensure higher future income.
} 
on choice of education level, but on the determinants behind the actual state transition from doctor to full professor.

A lthough our data set includes information as far back as 1895, when the renowned economist $\mathrm{Knut} W$ icksell presented his doctoral thesis, the analysis is concentrated to the period after the Second W orld W ar (i.e., the period between 1951 and 1989). In the early years, the process generating full professors was distinctly different from that of later years; the successful completion of a thesis used to be an almost certain guarantee of a chair, whereas in later years a number of different factors may influence the appointment process.

In this paper, we study the process of becoming a professor of economics in Sweden by means of event history analysis, where statistical methods are used to analyse time intervals between successive state transitions or events. Compared to traditional time-series or panel data, event histories are often better suited to the dynamic character of empirical phenomena. $^{2}$

\section{E conometric M ethodology}

The analysis is carried out by applying event history models in an economic setting. The general model is a continuous-time model which defines a state space and the set of feasible transitions between states. We treat the time after presentation of a thesis as a stochastic variable which defines the waiting time for becoming a full professor. If the person becoms a full professor before the end of the observation period, the waiting-time period is an uncensored spell; if not, it is a censored spell.

To estimate the risk of leaving the doctor ${ }^{3}$ state, the conditional hazard at duration thas the following functional form from the origin state:

$\mathrm{h}(\mathrm{t})=\exp \left\{\bar{\alpha}_{1}+\mathrm{x}^{\prime} \beta\right\} \quad$ if $\mathrm{t} \in \mathrm{I}_{\text {I }}$

where $I$ denotes the time period. By splitting points on the time axis $0=\tau_{1}<\tau_{2}<\tau_{3} \ldots<\tau_{m}$ with $\tau_{m+1}=\infty$, we get $m$ time periods $\mathrm{I}_{1}=\left\{\mathrm{t} \mid \tau_{1} \leq \mathrm{t}<\tau_{1+1}\right\} \mathrm{I}=1,2, \ldots, \mathrm{m}$ and, for the transition, the constant $\bar{\alpha}_{1}$ is a coefficient associated with the Ith time period. $x$ is a row vector of explanatory variables, and $\beta$ is an associated vector of coefficients assumed not to vary across time periods. The parameters of the model are estimated by the maximum-likelihood method. Under certain slight restrictions, these parameters are consistently estimated and asymptotically normal.

\footnotetext{
${ }^{2} \mathrm{~A}$ comprehensive theoretical overview and plentiful examples of empirical studies in the field may be found in K iefer (1988), B lossfeld, H amerle and M ayer (1989), L ancaster (1990) and Blossfeld and R ohwer (1995).

${ }^{3}$ In this study, we use the term doctor to denote all individuals with a doctoral degree who have not attained the position of full professor.
}

(c) The editors of the Scandinavian J ournal of E conomics 1997. 


\section{The Swedish Post-G raduate System, Data and Variables}

The development of the economics discipline in Sweden may be characterized in terms of four different evolutionary phases or periods: "The Founding Fathers", approximately 1889-1926 (David Davidson was appointed professor at U ppsala U niversity, K nut W icksell at L und U niversity, G ustav Cassel at Stockholm College and Eli H eckscher at the Stockholm School of Economics); "The Stockholm School", approximately 1927-50 (the height of Swedish economics, represented by distinguished scholars such as Gunnar M yrdal, Bertil O hlin, E rik Lundberg and E rik Lindahl); "Welfare State E conomics", approximately 1950- 75 (a period dominated by empirical macro- and microeconomics with applications to the expanding public sector); and "Economics the American Way", approximately 1975-89 (a period inspired by American research and characterized by diversification into new fields and a strong mathematical orientation) ${ }^{4}$

The complete data set comprises information on 374 doctoral theses in economics presented between 1895 and 1993, and their 380 authors. We rely on W adensjö's (1992) list of dissertations for 1895-1989, and on his unpublished list for 1990-93. We also use Gunnarsson's (1992) list of full professors of economics in Sweden from 1741-1989, supplemented by those few individuals who have become professors abroad and by those who were appointed in Sweden 1990-93 according to Sveriges Statskalender [O fficial Y earbook of Sweden] (1993).

For the sake of completeness and to provide a general overview, we present summary statistics for the entire period between 1895 and 1993 in Table 1. Since institutional characteristics as well as academic requirements and traditions between 1895 and the period immediately following WWII were distinctly different from those prevalent during the years of "W elfare State Economics" and "E conomics the A merican Way", our analysis focuses on the latter period.

The actual selection of a professor is based on evaluation reports by a committee, usually consisting of three senior professors (generally suggested by all Swedish economics departments). U ntil 1974, the final appointment of a full professor was made by the K ing-in-Council. B etween 1974 and 1988, appointments of tenured professors were made by the G overnment based on the recommendation of the university in question. From the end of the 1970s until 1988, "extra" professors were also appointed by the universities. Between 1988 and 1993, the Government or

${ }^{4}$ For a more detailed discussion of the different phases of Swedish economics, see J onung (1992). 
the universities made the appointments. Since 1993, however, appointments are made solely by the unversities themselves.

A ccording to the prevailing regulations, it is possible to become a full professor up until the age of 65 . Consequently, this bound is the upper limit in our calculations. In the case of doctors who died before this age, we use date of death, when known, as the upper limit. Similarly, it is most unlikely that economists become full professors within two to three years of their doctoral dissertations. Consequently, we restrict the sample by selecting 1989 as the last year of analysis. ${ }^{5}$ The number of observations is thus reduced from 340 to 256 .

In economic theory there are three major models that explain the function and role of education in society. A ccording to traditional economic theory, education may be seen as an investment in human capital and primarily regarded as a function of changes in the profitability of such an investment. A part from this original theory, a number of theories and hypotheses have emerged that may be characterized in terms of the function attributed to education: education regarded as consumption and education regarded as a screening process or filter.

These theories, however, are better suited to the study of investment in education for future earnings. Investments made in order to become a full professor are different from investments in education. In Sweden, although wages differ with education level, the prospect of higher income opportunities is not a probable driving force for an individual aspiring to become a full professor. Most often, the case is the opposite, i.e., an academic researcher (professor) does not earn as much as an academically inactive economist. U nquantifiable factors such as scientific satisfaction and higher social status may be regarded as more plausible reasons for such an investment.

A lthough the general framework of the above models may provide some understanding of issues related to the educational choices of individuals, or of the relations between education and earnings, the models do not suffice to provide determinants of the state transition from doctor to full professor. The fact that there is no fully developed model in this field should not, however, present an insurmountable obstacle. We can still establish some working hypotheses:

(i) A ge is negatively related to the risk of becoming a full professor.

(ii) B eing female reduces the risk of becoming a professor. O ther studies make it difficult to neglect this variable. In a study of departments of economics, Koplin and Singell (1996) concluded that their "findings

\footnotetext{
${ }^{5}$ It should be noted that the sample contains information on all doctoral theses up to and including 1989, and on all professors appointed up to and including 1993.
}

(c) The editors of the Scandinavian J ournal of E conomics 1997. 
are consistent with the existence of employment discrimination in research-oriented departments", W ennerås and Wold (1996) found that gender influenced the scores for "competence" given to applicants for post-doctoral fellowships in medicine in 1995, while G oggin (1992) found that female historians had been discriminated against in different ways.

(iii) The choice of an internationally fashionable and productive research field is positively related to the risk of becoming a professor.

(iv) Choice of university is important. Dixit, Honkapohja and Solow (1992) have pointed to differences in post-graduate training among Swedish universities.

(v) The variable faculty opponent is a measure of a doctor's level of activity. Since this quality is most certainly appreciated among those who exert influence on professorial appointments, it should be positively related to the risk of becoming a full professor.

A II of the variables included in the study and their summary statistics are listed in Table 1; they provide an overview of key features of the postgraduate tradition in the discipline for almost a century. O bviously, the profile of the individuals who have presented theses in economics, as well as that of the theses themselves, has changed over time with respect to a number of vital characteristics.

B oth the number of theses and the age (both mean and median) of the authors increased steadily over the periods. A t the beginning of the 1970s, new rules for the doctoral degree were introduced to shorten the time spent taking the degree and the required length of the thesis. Although these changes apparently did not have the effects intended, they probably constitute the main reason for the dramatic increase in the number of theses since the 1970s.

The mean waiting time (average time before the doctor becomes a full professor) decreased over the four periods, from 20.79 years in 1895- 1926 to 7.92 years in $1976-93$. H owever, the value 7.92 underestimates the mean waiting time, since it does not allow sufficient time for doctors who defended their theses during the final years to become full professors. During the period of study, the mean waiting time was 13.17 years.

The international influence on Swedish economics has gradually increased and changed direction. Thus, in the period 1895-1929, 74 per cent of all theses were in Swedish, 22 per cent were in German and only 4 per cent were in English. Between 1990 and 1993, however, 4 per cent of the theses were in Swedish while 96 per cent were in English. (These figures are not included in Table 1.)

A lthough the proportion was reduced during the last period of study, when $\mathrm{G}$ othenburg produced the highest number of doctors of economics, 
Table 1. Summary statistics

\begin{tabular}{|c|c|c|c|c|c|c|}
\hline \multirow[t]{2}{*}{ Variables } & \multirow[t]{2}{*}{ (1) } & \multirow[t]{2}{*}{ (2) } & (3) & (4) & \multirow[t]{4}{*}{$(3+4)$} & \multirow[t]{4}{*}{ (5) } \\
\hline & & & Welfare & Economics & & \\
\hline Mean & Founding & Stockholm & State & American & & \\
\hline (Std) & Fathers & School & Economics & Way & & \\
\hline Median & 1895- 1926 & $1927-50$ & $1951-75$ & $1976-93$ & 1951-93 & 1951-89 \\
\hline Number of observations & 19 & 21 & 75 & 265 & 340 & 256 \\
\hline \multirow[t]{3}{*}{ Age at defence of doctoral thesis } & 33.79 & 34.14 & 36.03 & 36.99 & 36.78 & 36.71 \\
\hline & $(5.66)$ & (4.95) & $(5.60)$ & $(5.08)$ & $(5.21)$ & (5.18) \\
\hline & 33.0 & 33.0 & 35.0 & 36.0 & 36.0 & 35.5 \\
\hline Name 1 if "Swedish" name & 1.000 & 1.000 & 0.867 & 0.717 & 0.750 & 0.769 \\
\hline 0 if not & $(0.00)$ & $(0.00)$ & $(0.342)$ & $(0.451)$ & $(0.434)$ & $(0.422)$ \\
\hline \multirow[t]{2}{*}{ Gender 1 if female, 0 if male } & 0.053 & 0.048 & 0.00 & 0.117 & 0.091 & 0.074 \\
\hline & $(0.229)$ & $(0.218)$ & $(0.00)$ & $(0.322)$ & $(0.288)$ & $(0.263)$ \\
\hline \multicolumn{7}{|l|}{ University: } \\
\hline \multirow[t]{2}{*}{ Others } & 0.000 & 0.000 & 0.040 & 0.030 & 0.032 & 0.039 \\
\hline & $(0.00)$ & $(0.00)$ & $(0.197)$ & $(0.171)$ & $(0.177)$ & (0.194) \\
\hline \multirow[t]{2}{*}{ Gothenburg } & 0.105 & 0.095 & 0.093 & 0.204 & 0.179 & 0.168 \\
\hline & $(0.315)$ & $(0.301)$ & $(0.293)$ & $(0.403)$ & $(0.384)$ & $(0.375)$ \\
\hline \multirow[t]{2}{*}{ Stockholm U niv. } & 0.368 & 0.571 & 0.333 & 0.196 & 0.226 & 0.238 \\
\hline & $(0.495)$ & $(0.507)$ & $(0.475)$ & $(0.398)$ & $(0.419)$ & $(0.427)$ \\
\hline \multirow[t]{2}{*}{ Stockholm SoE } & 0.00 & 0.048 & 0.187 & 0.128 & 0.141 & 0.144 \\
\hline & $(0.00)$ & $(0.218)$ & $(0.392)$ & $(0.335)$ & $(0.349)$ & $(0.352)$ \\
\hline \multirow[t]{2}{*}{ U ppsala } & 0.211 & 0.095 & 0.147 & 0.136 & 0.138 & 0.121 \\
\hline & $(0.419)$ & $(0.300)$ & $(0.356)$ & $(0.343)$ & $(0.346)$ & $(0.327)$ \\
\hline \multirow[t]{2}{*}{ Lund } & 0.316 & 0.190 & 0.187 & 0.173 & 0.176 & 0.195 \\
\hline & $(0.478)$ & $(0.402)$ & $(0.392)$ & $(0.379)$ & $(0.382)$ & $(0.397)$ \\
\hline \multicolumn{7}{|l|}{ Thesis' language } \\
\hline 1 if English or German & 0.263 & 0.190 & 0.440 & 0.755 & 0.685 & 0.590 \\
\hline 0 if Swedish & $(0.452)$ & $(0.402)$ & $(0.500)$ & $(0.431)$ & $(0.465)$ & $(0.493)$ \\
\hline Number of pages/1000 & 0.257 & 0.364 & 0.273 & 0.227 & 0.237 & 0.257 \\
\hline$(0.00-0.95) *$ & $(0.173)$ & $(0.193)$ & $(0.119)$ & $(0.114)$ & $(0.117)$ & $(0.123)$ \\
\hline $\begin{array}{l}\text { Proportion of pages with mathematical } \\
\text { function }(0.00-0.80)^{*}\end{array}$ & $\begin{array}{c}0.031 \\
(0.075)\end{array}$ & $\begin{array}{c}0.058 \\
(0.091)\end{array}$ & $\begin{array}{c}0.191 \\
(0.186)\end{array}$ & $\begin{array}{c}0.270 \\
(0.366)\end{array}$ & $\begin{array}{c}0.253 \\
(0.336)\end{array}$ & $\begin{array}{c}0.226 \\
(0.188)\end{array}$ \\
\hline
\end{tabular}


Table 1 - Continued

\begin{tabular}{|c|c|c|c|c|c|c|}
\hline $\begin{array}{l}\text { Variables } \\
\text { Mean } \\
\text { (Std) } \\
\text { Median }\end{array}$ & $\begin{array}{l}\quad(1) \\
\text { Founding } \\
\text { Fathers } \\
\text { 1895-1926 }\end{array}$ & $\begin{array}{l}\quad(2) \\
\text { Stockholm } \\
\text { School } \\
\text { 1927-50 }\end{array}$ & $\begin{array}{l}\quad(3) \\
\text { Welfare } \\
\text { State } \\
\text { Economics } \\
\text { 1951-75 }\end{array}$ & \begin{tabular}{l}
\multicolumn{1}{c}{$(4)$} \\
Economics \\
American \\
Way \\
$1976-93$
\end{tabular} & 1951-93 & 1951-89 \\
\hline $\begin{array}{l}\text { Proportion of pages with } \\
\text { quantitative methods }(0.00-0.39) *\end{array}$ & $\begin{array}{c}0.005 \\
(0.021)\end{array}$ & $\begin{array}{r}0.0009 \\
(0.004)\end{array}$ & $\begin{array}{c}0.029 \\
(0.052)\end{array}$ & $\begin{array}{l}0.067 \\
(0.098)\end{array}$ & $\begin{array}{c}0.059 \\
(0.091)\end{array}$ & $\begin{array}{c}0.045 \\
(0.059)\end{array}$ \\
\hline $\begin{array}{l}\text { Proportion of pages with } \\
\text { statistical tables }(0.00-0.56)^{*}\end{array}$ & $\begin{array}{c}0.136 \\
(0.162)\end{array}$ & $\begin{array}{c}0.166 \\
(0.162)\end{array}$ & $\begin{array}{l}0.126 \\
(0.122)\end{array}$ & $\begin{array}{c}0.096 \\
(0.156)\end{array}$ & $\begin{array}{c}0.103 \\
(0.150)\end{array}$ & $\begin{array}{c}0.108 \\
(0.110)\end{array}$ \\
\hline $\begin{array}{l}\text { Proportion with pages with } \\
\text { theoretical figures (0.00-0.34)* } \\
\text { Classification codes for theses: }\end{array}$ & $\begin{array}{c}0.004 \\
(0.014)\end{array}$ & $\begin{array}{c}0.030 \\
(0.057)\end{array}$ & $\begin{array}{c}0.041 \\
(0.049)\end{array}$ & $\begin{array}{c}0.031 \\
(0.044)\end{array}$ & $\begin{array}{c}0.033 \\
(0.046)\end{array}$ & $\begin{array}{c}0.036 \\
(0.046)\end{array}$ \\
\hline $\begin{array}{l}\text { O- General Economics, } \\
\text { Theory, History }\end{array}$ & $\begin{array}{c}0.474 \\
(0.513)\end{array}$ & $\begin{array}{c}0.381 \\
(0.498)\end{array}$ & $\begin{array}{c}0.280 \\
(0.452)\end{array}$ & $\begin{array}{c}0.121 \\
(0.326)\end{array}$ & $\begin{array}{r}0.156 \\
(0.363)\end{array}$ & $\begin{array}{c}0.168 \\
(0.375)\end{array}$ \\
\hline $\begin{array}{l}\text { 1- Economic Growth, } \\
\text { Development, Planning }\end{array}$ & $\begin{array}{c}0.053 \\
(0.229)\end{array}$ & $\begin{array}{c}0.095 \\
(0.301)\end{array}$ & $\begin{array}{c}0.067 \\
(0.251)\end{array}$ & $\begin{array}{c}0.132 \\
(0.339)\end{array}$ & $\begin{array}{r}0.118 \\
(0.323)\end{array}$ & $\begin{array}{c}0.125 \\
(0.331)\end{array}$ \\
\hline
\end{tabular}

* M in and Max values in parentheses. 
Table 1 - Continued

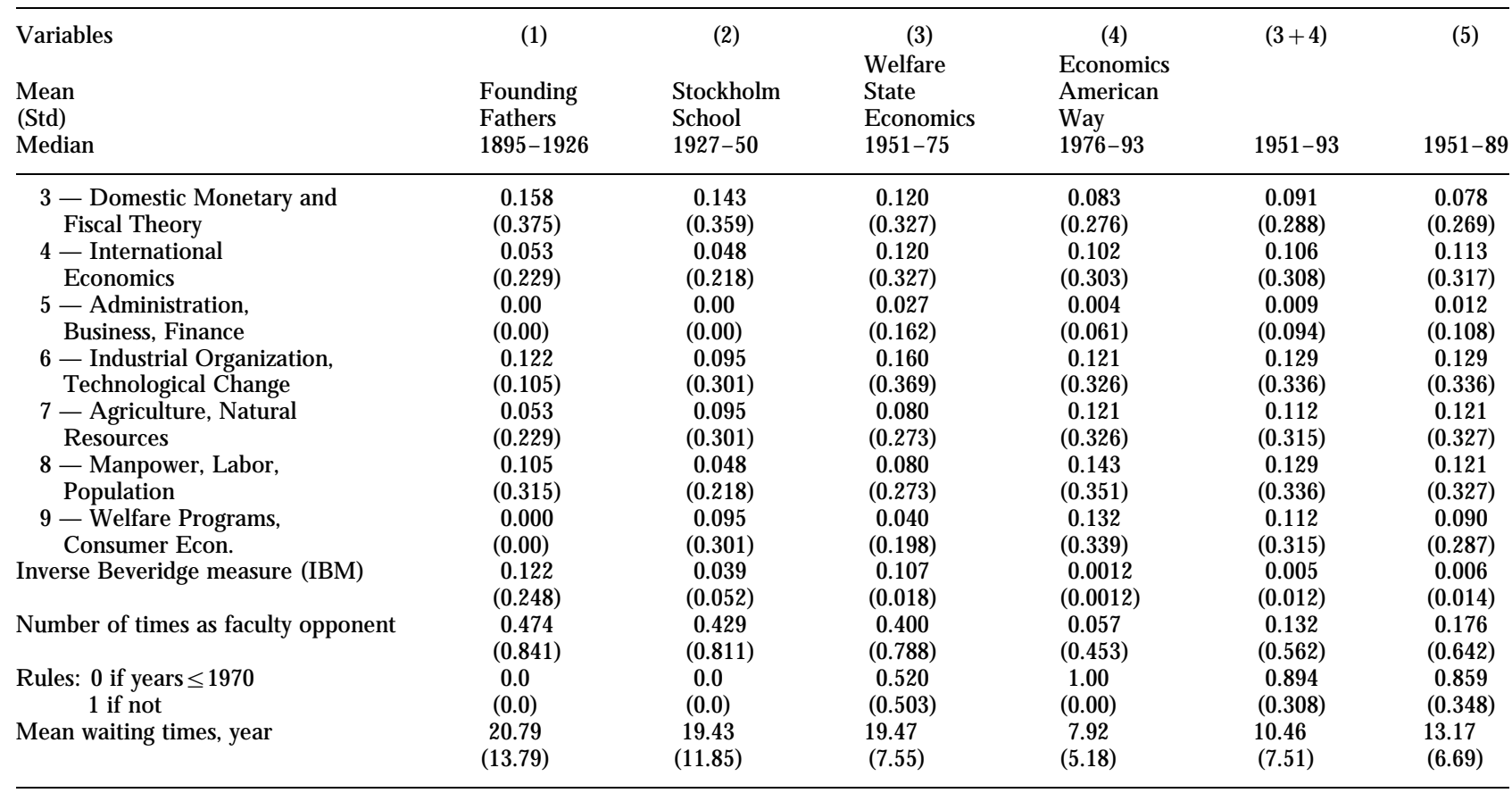

*M in and Max values in parentheses. 
more than a third of the doctoral degrees in economics are from Stockholm (Stockholm U niversity and the Stockholm School of E conomics).

The gender proportions are striking: only 9 per cent of the doctors are women. Although the first women, Margit Cassel and Karin Kock, presented their theses as early as 1924 and 1929, respectively, most researchers and lecturers at Swedish universities are still men. Between 1951 and 1975 there was not a single thesis written by a woman. The proportion of female Ph.D. students, however, has gradually been growing during the last decades; 18 per cent were women in 1989.

A s expected, the technical revolution is reflected in the steadily increasing complexity of theses as measured by the proportion of mathematics and quantitative methods applied. A s indicated by the classification codes, there has also been pronounced diversification into new fields.

The inverse B everidge measure (IBM ) is calculated as the ratio between the number of professors appointed during a given year ${ }^{6}$ to the number of the last 20 years' stock of doctors who have not become full professors. The variable corresponds to the ratio between vacancy and unemployment used in labour economics. Compared to period (3), the IBM value is considerably lower in period (4). Of course, in the academic market, the chance of becoming a full professor will increase along with the official opportunities of becoming a full professor. The low value during period (4) reflects the fact that there were relatively many doctors and few appointments. ${ }^{7}$

\section{Empirical Results}

As might be expected, the hazard risk of becoming a full professor of economics in Sweden increases during the years immediately after the doctor has defended his/her thesis. Figure 1 presents the hazard functions for three different periods, "Welfare State Economics" (period 3), 1951-75, "E conomics the A merican Way" (period 4), 1976-93 and the chosen period of study (period 5), 1951-89. The non-parametric graphs are based on life-table estimates.

Except for period (4), the hazard risk first increases and then decreases. Since the observation window is not yet terminated for period (4), the risk is incresing over the period. A lthough the non-parametric hazard graphs

\footnotetext{
${ }^{6}$ D uring some years, no professors were appointed but doctoral theses were presented. In order not to lose information in model estimations, we used the closest year forward during which appointments actually occurred as the appointment year.

${ }^{7}$ See e.g. Engwall (1992) for a thorough historical overview of the economics discipline in Sweden, an evaluation of the present educational system and comparisons between research conditions in Sweden and the U .S. See also Sandelin (1991) and Sandelin and V eiderpass (1997) who study different aspects of the internationalization of Swedish economics.
} 


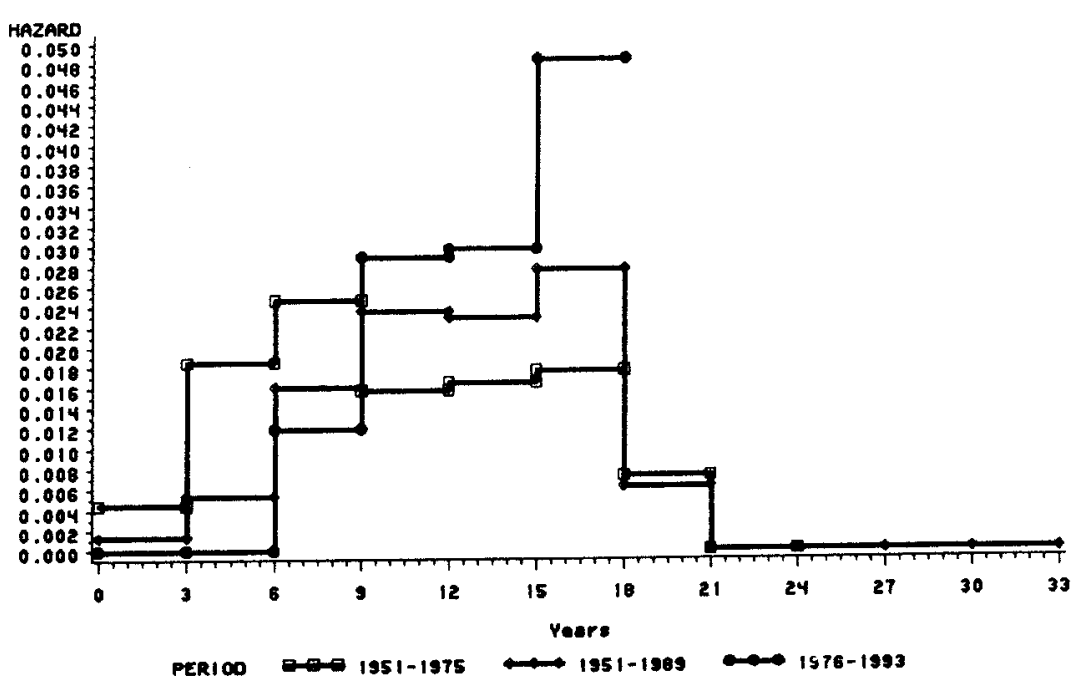

Fig. 1. Life-table hazard estimates, periods 1951-75, 1976-93 and 1951-89

display similar shapes for periods (3) and (5), the waiting times before reaching the highest risk are different. During period (3), academically active researchers face the highest risk after 10 years, while the highest risk occurs after 15 to 18 years during the period of study. $R$ isks are very low after 18 years' waiting time.

Consequently, an initially increasing and then decreasing shape seems appropriate as a hazard curve. In order to capture this type of duration dependency, we used both a piecewise constant exponential model and a quadratic model. To determine the appropriate length of the time periods, we made repeated tests to find out when the parameters of different time segments provided significant estimates. We found that a piecewise constant exponential model with explanatory variables would fit the data best. By means of a graphic test we found that, compared to the quadratic model, the piecewise constant exponential model performs more accurately with respect to the chosen time periods.

Thus, Table 2 shows results ${ }^{8}$ based on a piecewise constant exponential function, chosen as the best representative of the duration dependence of becoming a full professor of economics. In the table, the "preferred"

\footnotetext{
${ }^{8}$ In order to avoid numerical problems, we scaled the duration variable and the variable age at defense of doctoral thesis, dividing by 100 .
}

(c) The editors of the Scandinavian J ournal of E conomics 1997. 
Table 2. Piecewise constant exponential model estimates

\begin{tabular}{|c|c|c|c|}
\hline $\begin{array}{l}\text { Parameter } \\
\text { (Standard Error) }\end{array}$ & $\begin{array}{l}\quad(1) \\
\text { "Preferred" } \\
\text { M odel } \\
\text { 1951-89 }\end{array}$ & $\begin{array}{l}\text { U nivariate } \\
\text { M odels } \\
1951-89\end{array}$ & $\begin{array}{l}\quad \text { (3) } \\
\text { M ultivariate } \\
\text { M odel } \\
\text { (A II V ariables) } \\
\text { 1951-89 }\end{array}$ \\
\hline \multicolumn{4}{|l|}{ Time periods (years) } \\
\hline $0-3$ & $\begin{array}{r}-6.969 \\
(2.165)\end{array}$ & & $\begin{array}{r}-8.837 \\
(2.909)\end{array}$ \\
\hline $3-6$ & $\begin{array}{r}-5.556 \\
(1.981)\end{array}$ & & $\begin{array}{r}-7.473 \\
(2.777)\end{array}$ \\
\hline $6-9$ & $\begin{array}{l}-4.351 \\
(1.932)\end{array}$ & & $\begin{array}{l}-6.186 \\
(2.749)\end{array}$ \\
\hline $9-12$ & $\begin{array}{r}-3.900 \\
(1.919)\end{array}$ & & $\begin{array}{l}-5.599 \\
(2.727)\end{array}$ \\
\hline $12-15$ & $\begin{array}{r}-3.693 \\
(1.895)\end{array}$ & & $\begin{array}{r}-5.362 \\
(2.709)\end{array}$ \\
\hline $15-18$ & $\begin{array}{l}-3.445 \\
(1.886)\end{array}$ & & $\begin{array}{l}-5.079 \\
(2.707)\end{array}$ \\
\hline $18-41$ & $\begin{array}{r}-5.901 \\
(2.078)\end{array}$ & & $\begin{array}{r}-7.683 \\
(2.856)\end{array}$ \\
\hline A ge at defence of doctoral thesis & $\begin{array}{r}-9.728 \\
(4.309)\end{array}$ & $\begin{array}{r}-14.623 \\
(4.130)\end{array}$ & $\begin{array}{c}-9.353 \\
(5.026)\end{array}$ \\
\hline $\begin{array}{l}\text { Thesis' language: } \\
\text { English }\end{array}$ & $\begin{array}{c}1.063 \\
(0.468)\end{array}$ & $\begin{array}{l}1.185 \\
(0.346)\end{array}$ & $\begin{array}{c}0.919 \\
(0.547)\end{array}$ \\
\hline $\begin{array}{l}\text { Proportion of pages with mathematical } \\
\text { function }\end{array}$ & $\begin{array}{l}2.348 \\
(0.957)\end{array}$ & $\begin{array}{c}2.469 \\
(0.730)\end{array}$ & $\begin{array}{c}1.731 \\
(1.039)\end{array}$ \\
\hline \multicolumn{4}{|l|}{$\begin{array}{l}\text { Classification codes for theses: } \\
\quad(2-\text { Quantitative } E \text { con. }+5-A \text { dmin. }\end{array}$} \\
\hline Business $+6-$ Industrial O rganization) & 0.0 & 0.0 & 0.0 \\
\hline $\begin{array}{l}0-\text { G eneral E conomics, } \\
\text { Theory, } \mathrm{H} \text { istory }\end{array}$ & $\begin{array}{l}2.123 \\
(1.090)\end{array}$ & $\begin{array}{c}2.841 \\
(1.033)\end{array}$ & $\begin{array}{c}2.989 \\
(1.291)\end{array}$ \\
\hline $\begin{array}{l}1 \text { - E conomic Growth, } \\
\text { D evelopment, Planning }\end{array}$ & $\begin{array}{l}2.445 \\
(1.181)\end{array}$ & $\begin{array}{c}2.349 \\
(1.097)\end{array}$ & $\begin{array}{l}3.577 \\
(1.387)\end{array}$ \\
\hline $\begin{array}{l}3 \text { - D omestic M onetary and } \\
\text { Fiscal Theory }\end{array}$ & $\begin{array}{l}2.803 \\
(1.230)\end{array}$ & $\begin{array}{c}1.771 \\
(1.155)\end{array}$ & $\begin{array}{c}4.156 \\
(1.426)\end{array}$ \\
\hline $\begin{array}{l}4 \text { - International } \\
\text { E conomics }\end{array}$ & $\begin{array}{c}2.761 \\
(1.165)\end{array}$ & $\begin{array}{c}2.359 \\
(1.080)\end{array}$ & $\begin{array}{c}3.677 \\
(1.381)\end{array}$ \\
\hline $\begin{array}{l}7-\text { A griculture, } N \text { atural } \\
\text { R esources }\end{array}$ & $\begin{array}{l}3.030 \\
(1.202)\end{array}$ & $\begin{array}{c}2.131 \\
(1.119)\end{array}$ & $\begin{array}{c}4.197 \\
(1.406)\end{array}$ \\
\hline $\begin{array}{l}8 \text { - M anpower, Labor, } \\
\text { Population }\end{array}$ & $\begin{array}{c}3.183 \\
(1.167)\end{array}$ & $\begin{array}{c}2.270 \\
(1.096)\end{array}$ & $\begin{array}{c}4.342 \\
(1.360)\end{array}$ \\
\hline $\begin{array}{l}9 \text { - W elfare Programs, } \\
\text { Consumer E con. }\end{array}$ & $\begin{array}{l}2.457 \\
(1.234)\end{array}$ & $\begin{array}{c}1.869 \\
(1.156)\end{array}$ & $\begin{array}{c}3.373 \\
(1.456)\end{array}$ \\
\hline Number of times as faculty opponent & $\begin{array}{c}0.489 \\
(0.134)\end{array}$ & $\begin{array}{c}0.366 \\
(0.111)\end{array}$ & $\begin{array}{c}0.702 \\
(0.181)\end{array}$ \\
\hline Log likelihood & -185.559 & & -178.799 \\
\hline N umber of parameters & 19 & 1 & 32 \\
\hline $\begin{array}{l}\text { N umber of censored observations } \\
\text { (M ean duration) }\end{array}$ & $\begin{array}{l}214 \\
(13.76)\end{array}$ & & \\
\hline $\begin{array}{l}\text { Number of uncensored observations } \\
\text { (M ean duration) }\end{array}$ & $\begin{array}{l}42 \\
(10.19)\end{array}$ & & \\
\hline $\begin{array}{l}\text { N umber of observations } \\
\text { (M ean duration) }\end{array}$ & $\begin{array}{l}256 \\
(13.17)\end{array}$ & & \\
\hline
\end{tabular}

Note: The complete list of estimates may be obtained from the authors on request. 
model (1) provides the results for the chosen period of study, 1951-89. Parameter estimates of univariate models for the same period are reported in column (2). E ach parameter estimate in this column is obtained from a specific model fitting; estimates of the seven time periods are therefore not reported. Column (3) contains estimated parameter results for a multivariate model for the period of study; in (2) and (3) we only report coefficients of the variables included in the "preferred" model.

A s might be expected, all significant estimates in the univariate models lose their power in the multivariate model. Some significant parameters lose power in absolute terms and become insignificant. This may be a consequence of the fact that the overall significance level falls as the number of explanatory variables now constitutes a large proportion of the total sample size.

The duration parameter estimates have the same signs for the univariate and multivariate models. Furthermore, the size of the parameters is very similar. F rom observing these estimates, we conclude that the hazard curve follows the shape of an inverse $U$.

The "preferred" model includes relatively more important factors explaining the phenomenon of becoming a full professor of economics in Sweden since W WII and, statistically, it fits the data well. Predicted residuals on the diagonal indicate a strong correspondence between the observed data and the model applied.

W ith the exception of the multivariate model (3), the parameter for the age at defence of a doctoral thesis is estimated to be negatively significant. Consequently, increasing age delays full professorship, and each additional year that passes before becoming a doctor reduces the hazard of becoming a full professor of economics.

Thesis language and the proportion of pages with mathematical equations have significantly positive effects on the hazard of becoming a full professor. The hazard risk is 2.9 times higher for authors who have written theses in E nglish compared to those who have written in Swedish. By using mathematical functions, the risk of becoming a full professor of economics also increases.

Thesis classification code is also important. If doctors choose a topic in the internationally fashionable and productive manpower, labour or population economics category, their risk of becoming a full professor is higher compared to that of the doctors choosing other topics.

The last parameter estimated to be significant in all of the models is number of times as faculty opponent. As pronounced diversification, specialization and international communication have made it increasingly difficult to be appointed faculty opponent (see Table 1 ), being active in this respect has a significantly positive impact on the prospects of becoming a full professor in Sweden. (Y oung faculty opponents may, of course, be 
appointed according to criteria correlated with those used when appointing professors.) All other coefficients are estimated to be insignificant.

By means of a score test procedure, the "preferred" model ${ }^{9}$ was tested for neglected unobserved heterogeneity. The value of the resulting test statistic, -0.140 , indicates that there is no neglected unobserved heterogeneity at any reasonable level of significance in the model. Consequently, it is hard to assert any impact of the individual-specific unobserved factor on the risk of becoming a full professor.

\section{Concluding Remarks}

Since this is the first time that the actual state transition from doctor to full professor in Sweden has been studied, we have sought guidance from contiguous models and drawn on the history and special characteristics of the topic when establishing our working hypotheses.

O ur findings with regard to all variables except gender and university support our hypotheses. The gender variable shares one common feature with other variables that were estimated to be insignificant: on average, their relative proportions are small. Not surprisingly, the variables age, classification codes for thesis, faculty opponent, mathematics and language (i.e., the use of English as one's thesis language) were found to be significant. During the period of study, the use of mathematics as well as internationalization have increased in economics, and it is only natural that those who have been at the forefront of this development are given credit. The importance of keeping in touch with international trends is also reflected in the classification codes and faculty opponent variables.

Based on these findings, we may offer the following points to aspiring Ph.D. students:

(i) Before taking your degree: A ge is a critical factor, complete your doctorate when you are as young as possible.

(ii) While working on your thesis: Choice of topic is most important. Y our preferred choice should be one that is currently popular and expanding internationally (such as labour economics during the period of study). In fact, it is imperative to be in touch with current trends, as indicated by the variables language and mathematics.

(iii) After taking your degree: Try to maximize your chances of being appointed faculty opponent.

\footnotetext{
${ }^{9}$ See Burdett et al. (1985) and Blossfield et al. (1989). In view of the fact that the parametric specification of the model may give a different result, the quadratic model was also tested for unobserved heterogeneity. The resulting value of the test statistic, -0.725 , is a further indication of the absence of unobserved heterogeneity.
} 


\section{References}

Becker, G. S.: H uman Capital: A Theoretical and E mpirical Analysis with Special Reference to E ducation. Columbia U niversity Press, N ew Y ork, 1964.

Blossfeld, H.-P. and Hamerle, A .: U nobserved heterogeneity in hazard rate models: A test and an illustration from a study of career mobility. In K. U. M ayer and N. B. Tuma (eds.), Event $\mathrm{H}$ istories Analysis in L ife Course Research, U niversity of W isconsin Press, M adison, WI, 1988.

Blossfeld, H .-P., H amerle, A . and M ayer, K. U .: E vent H istory A nalysis: Statistical Theory and Application in the Social Sciences. Lawrence Erlbaum Associates Inc., Hillsdale, NJ, 1989.

Blossfeld, H .-P. and R ohwer, G.: Techniques of E vent History M odeling: New Approaches to Causal Analysis. Lawrence E rlbaum A ssociates Inc., M ahwah, NJ , 1995.

Burdett, K., K iefer, N. M . and Sharma, S.: L ayoffs and duration dependence in a model of turnover. J ournal of E conometrics 28, 51-69, 1985.

Dixit, A. K., Honkapohja, S. and Solow, M.: Postgraduate education in Sweden. In L. Engwall (ed.), E conomics in Sweden, R outledge, London and N ew Y ork, 1992.

Engwall, L. (ed.): E conomics in Sweden. R outledge, London and N ew Y ork, 1992.

Goggin, J.: Challenging sexual discrimination in the historical profession: W omen historians and the A merican H istorical A ssociation, 1890-1940. American Historical Review 97 (3), 769-802, 1992.

G unnarsson, E.: Professors of economics in Sweden, 1741-1989. A ppendix B in L. Engwall (ed.), E conomics in Sweden, R outledge, London and New Y ork, 1992.

J onung, L.: E conomics the Swedish way, 1889-1989. In L. Engwall (ed.), Economics in Sweden, R outledge, London and N ew Y ork, 1992.

K iefer, N. M .: E conomic duration data and hazard functions. J ournal of E conomic L iterature 26, 646-79, 1988.

Koplin, V. W. and Singell, L. D., J r.: The gender composition and scholary performance of economics departments: A test for employment discrimination. Industrial and Labor Relations Review 49 (3), 408-423, 1996.

Lancaster, T.: The Econometric Analysis of Transition Data. Cambridge U niversity Press, Cambridge, 1990.

$M$ incer, J.: Investment in human capital and personal income distribution. J ournal of Political E conomy LXVI (4), 291-302, 1958.

Sandelin, B. (ed.): The H istory of Swedish Economic Thought. R outledge, L ondon, 1991.

Sandelin, B. and V eiderpass, A .: The dissolution of the Swedish tradition. History of Political E conomy 28, 1997.

Schultz, T. W .: Investment in human capital. American E conomic Review 51, 1-17, 1961.

Wadensjö, E.: Doctoral theses in economics in Sweden 1895-1985. Appendix D in L. E ngwall (ed.), E conomics in Sweden, R outledge, London and N ew Y ork, 1992.

W ennerås, C. and Wold, A.: Peer review for males. D epartment of M edical M icrobiology and Immunology and Department of Clinical Immunology, Gothenburg U niversity, 1996.

First version submitted D ecember 1994;

final version received A pril 1997. 